\title{
Ambulance Operational Services Information System At The Jakarta Department Of Health
}

\author{
Sri Rahayu ${ }^{* 1}$, Desti Nanda Pramesti ${ }^{2}$, Dira Aulia Aditya ${ }^{3}$ \\ ${ }^{1,2,3}$ Raharja University, Faculty of Science and Technology, Department of Technical \\ Information \\ E-mail: ${ }^{* 1}$ srirahayu@ raharja.info, ${ }^{2}$ desti.nanda@ raharja.info, ${ }^{3}$ dira.aulia@raharja.info
}

\begin{abstract}
Information regarding monitoring of operational expenditures of the Regional Public Service Agency at the Emergency Ambulance Service Unit of the DKI Jakarta Health Office. Because the finances issued or used must be accurately informed. In this case, monitoring the operational expenses of the Regional Public Service Agency at the Emergency Ambulance Service Unit of the DKI Jakarta Health Service still has many obstacles. Constraints faced are such as the technical executor. The activity of submitting an accountability letter still has a long stage, the Verifier is not there so that the process of checking the accountability letter stops, the input of reports is carried out one by one by the Spending Treasurer using Microsoft Excel. The process of monitoring the operational expenses of the Regional Public Service Agency at the Emergency Ambulance Service Unit of the DKI Jakarta Health Office takes a long time. And another obstacle is the occurrence of classifying the type of operational expenditure. In this data analysis method, using Balanced Scorecard (BSC) analysis, system design uses Visual Paradigm to create UML (Unified Modeling Language), PHP programming language, MySQL to create databases. The result of this research is that an information system for monitoring operational expenditures of the Regional Public Service Agency can create and submit a letter of accountability and verification letters are carried out computerized, the Expenditure Treasurer no longer enters the general cash books one by one, the Expenditure Treasurer no longer classifies the types of operational expenditure in recap operational expenditure.
\end{abstract}

Keywords — Monitoring, Expenses, Operational

\section{INTRODUCTION}

Information is a very important medium for everyone. According to Muhamad Ilham, Wina Witanti, Herdi Ashaury in the journal SAINTEKS (2020: 113) argues that monitoring aims to assess whether the activities carried out are in accordance with the plan. CV. Information regarding monitoring of operational expenditures of the Regional Public Service Agency at the Emergency Ambulance Service Unit of the DKI Jakarta Health Office. Because the finances issued or used must be well informed and accurate. The process of submitting an accountability letter depends on the inspection process carried out by the Verifier. After verification, the Expenditure Treasurer performs the process of disbursing funds and inputs the general cash book in Microsoft Excel. After the month ends, at the beginning of the month the Expenditure Treasurer recapitulates operational expenditures, namely classifying the types of expenditure costs to be given to the Regional Government and the Finance section of the 
Regional Public Service Agency monitors operational expenditures to be given to the Unit Head in the DKI Jakarta Health Service Emergency Ambulance Service Unit. .

The obstacles that are faced at this time are the technical executor of the activity of submitting an accountability letter which still has a long stage, the Verifier is not there so that the process of checking the accountability letter has stopped, the input of reports is carried out one by one by the Expenditure Treasurer and still uses Microsoft Excel. So that the process of monitoring the operational expenses of the Regional Public Service Agency at the Emergency Ambulance Service Unit of the DKI Jakarta Health Office takes a long time. And other obstacles, such as frequent errors in classifying the types of operational expenditures.

From the problems that have been analyzed, the authors designed a web-based information system for monitoring operational expenditures of the Regional Public Service Agency. So that it can speed up the process of monitoring the operational expenses of the Regional Public Service Agency in the DKI Jakarta Emergency Ambulance Service Unit. The information system for monitoring operational expenditures of Regional Public Service Agencies is implemented, submitting accountability letters is faster, classifying types of operational expenditures is more accurate, and easing the financial work of regional public service agencies, namely the Regional Public Service Agency's Finance no longer monitoring operational expenses.

\section{The scope of research}

The author provides limitations based on the scope of the research, including:

a. The process of making a letter of responsibility,

b. The process of checking the completeness of the letter of accountability,

c. The process of making a general cash book,

d. The process of making an operational expenditure recap

e. The process of monitoring operational expenses.

\section{RESEARCH METHOD}

Research Methods (can include analysis, architecture, methods used to solve problems, implementation), in this discussion the author can describe how the research will be carried out. In this study, the authors used the following methods:

\section{Method of collecting data}

1. Observation.

In this observation, the authors directly reviewed the research site to the Information Technology (IT) section and the Expenditure Treasurer in the Emergency Ambulance Service Unit of the DKI Jakarta Health Office. To get more accurate data.

2. Interview.

In this interview, the author conducted a question and answer session to Mr. Adityo as Information Technology (IT), Mrs. Rizka as Treasurer of Expenditure and Mr. Christian as Finance of the Regional Public Service Agency. To obtain information related to monitoring operational expenditures of the Regional Public Service Agency. 
3. Literature Study

In this literature study, the authors conducted a literature study by looking for references from online books and journals related to this research.

\section{Data Analysis Method.}

In the data analysis method, the authors analyzed the data using the Balanced Scorecard (BSC) analysis. So that it can be accessed by staff who occur in the Emergency Ambulance Service Unit of the DKI Jakarta Health Office.

\section{System Design Methods.}

In this system design method, the authors carry out a system design using Visual Paradigm to create UML (Unified Modeling Language), database design, to costs which contain details of system costs.

\section{Testing Method}

In the test method, the author uses BlackBox Testing to find errors and the feedback provided by the system when it is operated whether it is as expected.

\subsection{Review Stages}

\section{Theoretical Basis}

\section{A. System}

According to Kasman Rukun and B. Herawan Hayadi in their book (2018: 2) states that the word system means a collection of components that have an element of interrelation with one another.

B. Data

According to Rahmad Mahmud, Jullie J. Sondakh, Novi S. Budiarso in the EMBA Journal (2016: 696) argues that data is a collection of information or information obtained from an observation, it can be numbers, symbols or characteristics.

C. Information

According to Arief Budiman and Joko Triono in the Technology Pillar Journal (2016: 44) argues that an information system can be interpreted as an integrated system capable of providing useful information for its users.

\section{Information Systems}

According to Santy Irene Putri and Prima Soultoni Akbar in their book (2019: 1) states that the definition of an information system is a system capable of producing information that can meet needs effectively and efficiently and can be used as a recommendation in determining decisions in an organization that has various kinds level.

\section{E. Monitoring}

According to Mulyono and Yumari in their book (2017: 9) states that according to government regulation Number 39 of 2006 , monitoring is an activity to carefully observe a situation or condition, including certain behaviors or activities, with the aim that all input data or information is obtained. from the results of these observations can be the basis for making further action decisions that are needed. 


\section{F. Spending}

According to Rundengan, quoted by Nurmalasari and Wahyu in the Evolution Journal (2019: 13) argues that cash disbursement is a record made to carry out expenditure activities either by check or with cash used for general company activities.

\section{G. Operational}

According to Sumadi Suryabrata quoted by Juhana Nasrudin in his book (2019: 20) states that an operational definition is a definition based on the properties of things that can be defined which can be observed.

\section{H. Regional Public Service Agency}

According to Halkadri Fitra and Henri Agustin in the Economac Journal (2018: 2), the Regional Public Service Agency is based on the Regulation of the Minister of Home Affairs (Permendagri) Number 61 of 2007 Regional Public Service Bodies, hereinafter abbreviated as BLUD, are Regional Work Units or Work Units in Units. The work of regional apparatus within the regional government which is formed to provide services to the community in the form of providing goods and services that are sold without prioritizing for profit, and in carrying out their activities based on the principles of efficiency and productivity.

\section{Accountability Letter}

According to Gray Panambunan and Jantje J. Tinangon in the EMBA Journal (2016: 912) argues that the Letter of Accountability (SPJ) is a document that explains the use of funds managed by the expenditure treasurer.

\section{J. Capital Expenditures}

According to Ayu and Arif quoted by Prima Rosita Arini S, Manggar Wulan Kusuma in the Mercu Buana Accounting Research Journal (2019: 30) argues that capital expenditure is expenditure that provides benefits for more than one year to increase regional assets or wealth, which will lead to spending other.

\section{K. Employee Spending}

According to Muhammad Idris Patarai in his book (2016: 270) argues that personnel expenditure is expenditure issued by the APBD for the benefit of government employees or bureaucrats.

L. Goods and services

According to Iswahyudin in e Journal of Catalogs (2016: 155) argues that goods and services expenditures are expenditures to accommodate the purchase of consumable goods and services to produce goods and services that are marketed or not marketed, and the procurement of goods intended to be delivered or sold to the public and shopping trips.

\section{Expenditure Treasurer}

According to the Balikpapan BDK quoted by Darman Umagapi and Syahril Hasan in the ILKOMINFO Scientific Journal (2019: 50), he argues that the Expenditure Treasurer is one of the State Treasury Officials who has the task of making payments for money within his authority. 


\subsection{Figures and Tables}

In this study, will explain the design of the operational expenditure monitoring system of regional public service agencies in the emergency ambulance service unit of the DKI Jakarta health department. In this study, the authors designed a proposed system that can assist operational activities in the process of monitoring operational expenditures of regional public service agencies at the Health Service Emergency Ambulance service unit. The process of monitoring the operational expenditures of regional public service agencies in the required health service emergency ambulance units will be easier. And the resulting reports will be more effective. In writing this scientific journal, the scope of research includes:

1) The process of making a letter of responsibility

2) The process of checking the completeness of the letter of accountability

3) The process of making a general cash book

4) The process of making an operational expenditure recap

5) The process of monitoring operational expenses

In the proposed system design which can be explained in use case diagrams, activity diagrams, sequence diagrams and class diagrams using Visual Paradigm for UML 6.4 Enterprise Edition.

\section{Current System Procedure Design}

Use Case Diagram of the Running System

1. Use Case Diagram of Accountability Letter Submission.

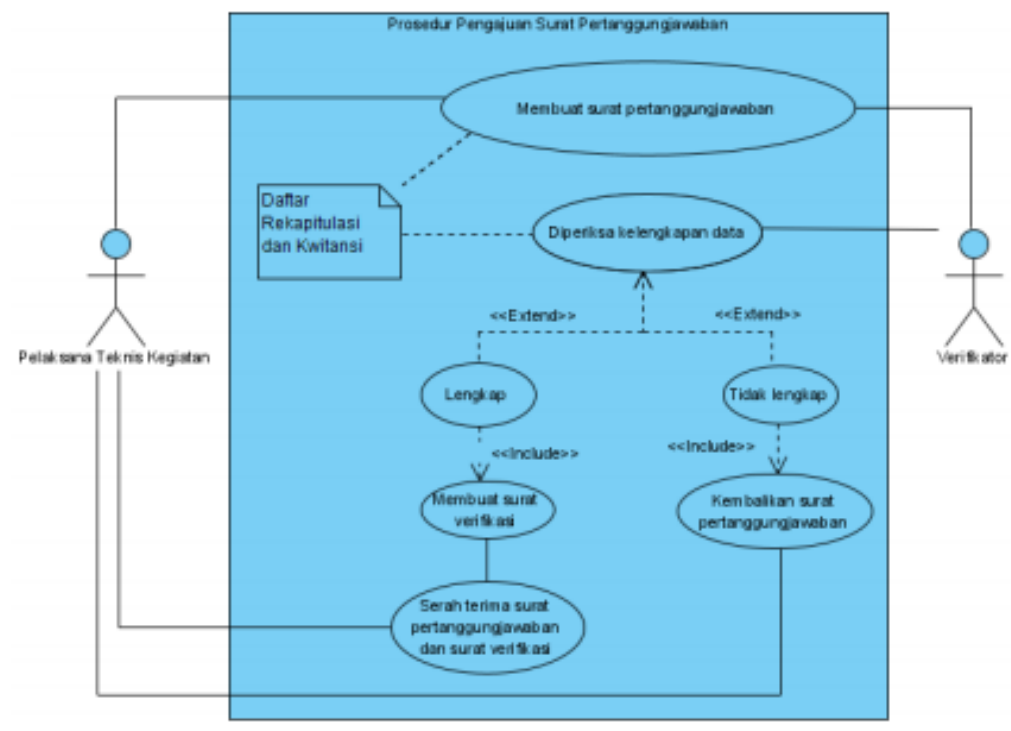

Figure 1 Use Case Diagram for Letter Submission

Based on the use case diagram above, there are:

a) All activities in the process of submitting an accountability letter.

b) There are two actors who carry out activities, including: Activity Technical Executor and Verifier.

c) There were seven use cases carried out by the actor

d) There is one note that is connected in two use cases. 
2. Use case diagram of operational expenditure expenses.

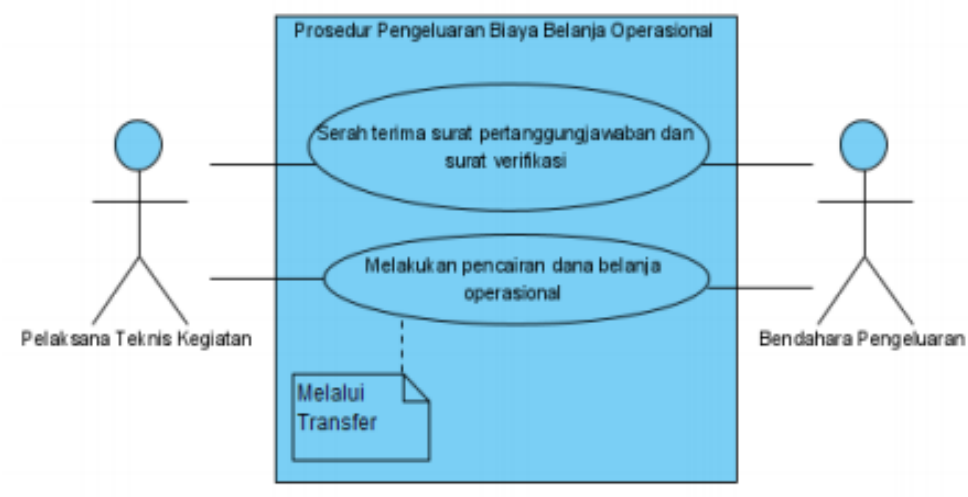

Figure 2 Use Case Diagram of Current Operational Expenditure Expenses

Based on the use case diagram above, there are:

a) All activities of the ongoing operational expenditure disbursement process.

b) There are two actors who carry out activities, including: Activity Technical Executor and Expenditure Treasurer.

c) There are two use cases carried out by the actor.

3. Use Case Diagrams for Reporting.

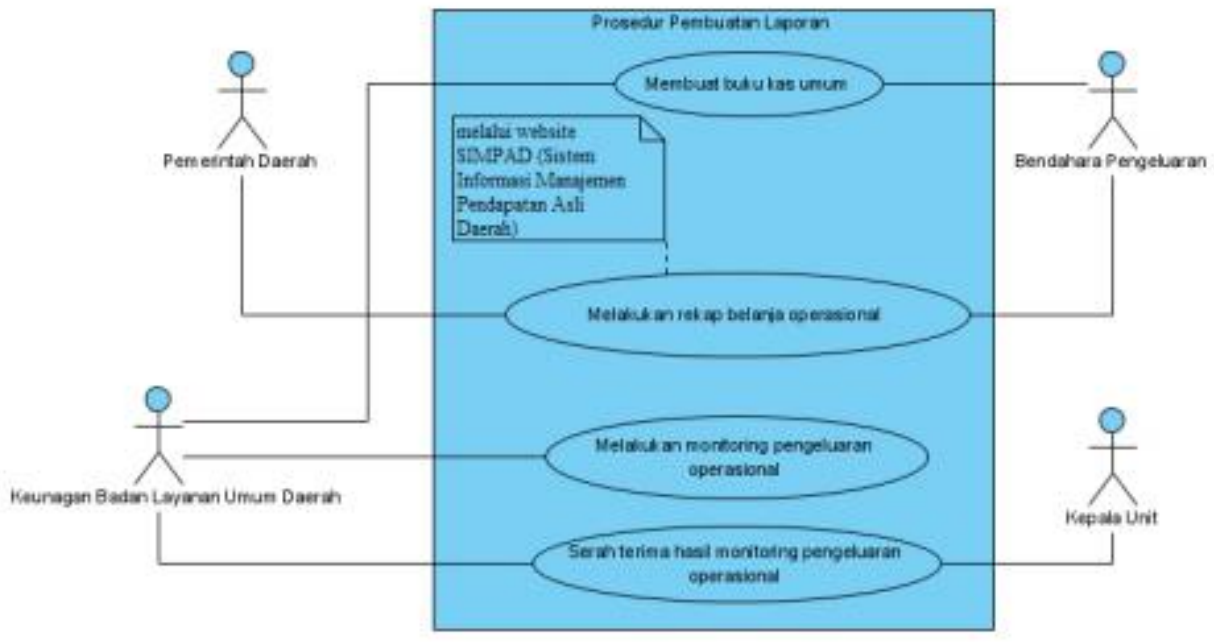

Figure 3 Use Case Diagram for Current Report Making

Based on the use case diagram above, there are:

a) All activities in the ongoing reporting process.

b) There are four actors who carry out activities, including: Expenditure Treasurer, Regional Public Service Agency Finance, Regional Government, Head of Unit.

c) There are four use cases and one note made by the actor. 


\section{Balance Scorecard Analysis Method}

This system analysis method is carried out before the design stage is carried out.

1. Vision and Mission of the Emergency Ambulance Service Unit of the DKI Jakarta Health Office.

1) Vision of the DKI Jakarta Health Service Emergency Ambulance Service Unit.

2) To be the best Emergency Ambulance service to a healthy Jakarta.

3) Mission of the DKI Jakarta Health Service Emergency Ambulance Service Unit.

4) Providing emergency ambulance services that are responsive, professional and have zero complaints.

5) Applying quality management principles at each level of service.

6) Become a referral center for ambulance and emergency training.

7) Become a referral center for ambulance and emergency training.

2. The relationship between the Vision, Mission and Strategy with the selected perspectives and strategic objectives.

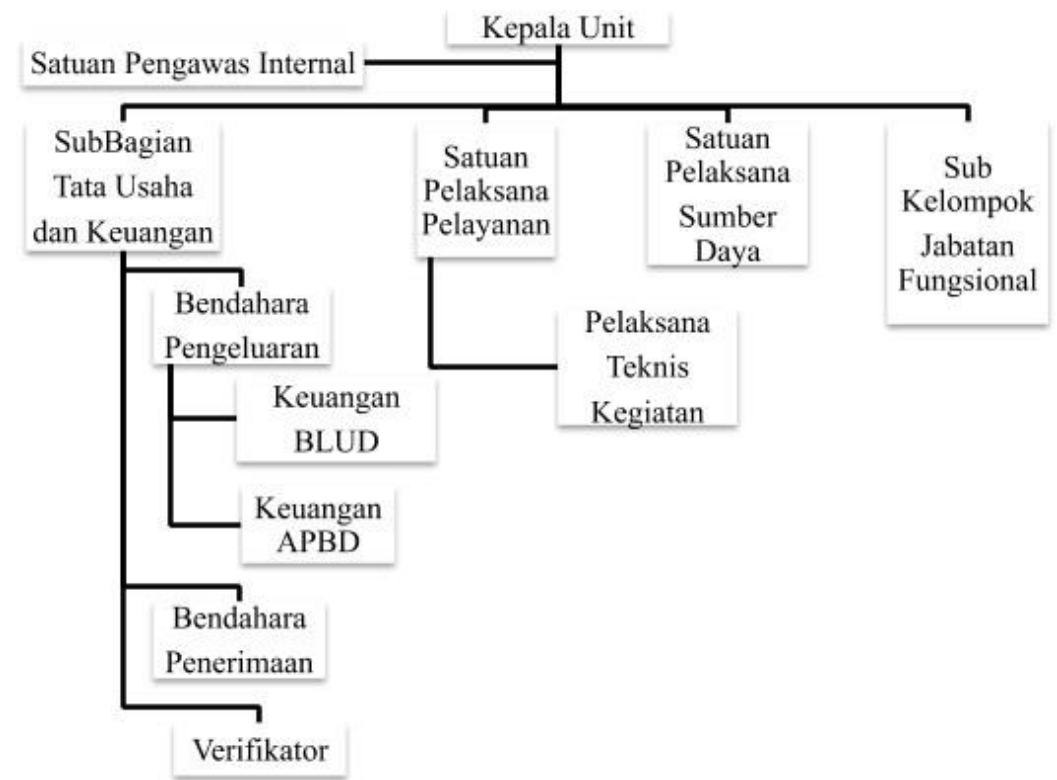

Figure 4. Balanced Scorecard for Emergency Ambulance Service Unit of DKI Jakarta Health Office

3. Characteristics of the balance scorecard

1) Financial

a. Expenditure Treasurer

b. Treasurer of Reception

c. Regional Public Service Agency Finance

2) Customer

a. Marketing

3) Business Process

a. Service Implementing Unit

4) Learn and growth

a. Implementing Resources Unit. 
4. Table of Results from Perspective

Table 1 Measures of Results from Perspective

\begin{tabular}{|c|c|c|c|c|}
\hline Departement & Objective & Measure & Target & Initiatives \\
\hline $\begin{array}{l}\text { Activity } \\
\text { Technical } \\
\text { Executor }\end{array}$ & $\begin{array}{l}\text { Emergency } \\
\text { ambulance } \\
\text { services and } \\
\text { training }\end{array}$ & $\begin{array}{l}\text { Accountability letter } \\
800,000 / \text { month } \\
\text { Receipt } \\
800,000 / \text { month }\end{array}$ & $75 \%$ & $\begin{array}{l}\text { Improve } \\
\text { service } \\
\text { quality. }\end{array}$ \\
\hline Treasurer & $\begin{array}{l}\text { 1.General } \\
\text { ledger } \\
\text { 2.Operational } \\
\text { expenditure } \\
\text { recapitulation }\end{array}$ & $\begin{array}{ll}\text { 1. } & \text { Rp. } \\
& 1.300 .000 .000 / \\
& \text { Month } \\
& \\
\text { 1. } & \text { Capital } \\
& \text { expenditure: } \\
& \text { Rp. 300.000.000 } \\
\text { /month } \\
\text { 2. Employee } \\
\text { purchasing: } \\
\text { Rp.300.000.000 } \\
\text { /month. } \\
\text { 3. Purchasing: } \\
\text { Rp. 700.000.000 } \\
\text { /month } \\
\end{array}$ & $75 \%$ & $\begin{array}{l}\text { Ensuring } \\
\text { the } \\
\text { appropriate } \\
\text { cost } \\
\text { allocation. }\end{array}$ \\
\hline Finance & & & & $\begin{array}{l}\text { control and } \\
\text { evaluation }\end{array}$ \\
\hline $\begin{array}{c}\text { Regional } \\
\text { Public Service }\end{array}$ & $\begin{array}{l}\text { Operational } \\
\text { Expenditure } \\
\text { Monitoring }\end{array}$ & $\begin{array}{l}\text { Rp. } 1.300 .000 .000 \\
\text { /month }\end{array}$ & $73,99 \%$ & $\begin{array}{l}\text { Absorption } \\
\text { of } \\
\text { operational } \\
\text { expenditure } \\
\text { does not } \\
\text { exceed the } \\
\text { reference } \\
\text { per year }\end{array}$ \\
\hline
\end{tabular}

\subsection{Reference Bibliography}

The following research has been carried out and is related to the research that will be discussed:

1) Research conducted by Muhamad Ilham, Wina Witanti, Herdi Ashaury (2020) with the title, Development of a Financial Monitoring Information System at CV Citra Lestari, in the SAINTEKS Journal [1]. This journal contains: Monitoring aims to assess whether the activities carried out are in accordance with the plan. CV. Sustainable image of company finance that is managed for company activities, both company income from 
sales, as well as recording financial data, purchasing raw materials, salary costs, other costs required in operational activities are still recorded in the books, in this way it can create a risk of error such as searching for data that takes a relatively long time, randomly stacked data, mismatches of data during sales or expenses, and lack of control over incoming and outgoing finances, this can potentially result in losses for the company. In addition, at the end of a certain period, either annually or monthly, the company makes a report, which is done by the finance department for the owner of the company. Reporting is done by taking the recording of transaction data recorded in a book, in this way it is felt that the reporting process is relatively long. So that when it is needed suddenly it cannot be fulfilled. In addition, it also has the risk of errors made by the financial department in calculating. It is expected to help solve problems more efficiently and effectively by building a financial monitoring information system at CV. Citra Lestari.

2) Research conducted by Syaulan Tsaqila, Gusmelia Testiana, Muhamad Kadafi (October 2018) with the title, Financial Administration Information System, Faculty of Science and Technology Uin Raden Fatah Palembang, in the National Seminar Journal of Applied Science and Technology [75]. In this journal contains about: The process of financial transactions at the Faculty of Science and Technology UIN Raden Fatah Palembang takes a long time in documenting files for reports and making reports on budget realization. This study aims to design and build a Financial Administration Information System (SI-AK) at the Faculty of Science and Technology UIN Raden Fatah Palembang in order to simplify the process of making financial reports, facilitate the financial department in monitoring budget realization, and provide information about the implementation of activities in accordance with the RKAKL. The research method used is a qualitative research method with data collection methods, namely observation, interviews, literature study, and documentation. The system development method used is the spiral. Analysis and design tools used are UML, and database design using ERD. The programming language used is PHP, the Codeigniter framework, and the database uses MySQL, the testing method uses Blackbox testing. It is hoped that the system can assist financial administration activities, especially in the budget realization activities.

3) Research conducted by Erlina and Sirojuzilam (February 2020) with the title, Socialization of the Application of the Web-Based BUMDES Financial Recording and Reporting System in RISET Journal and Accounting Journal Vol. 4 No.1 [79]. This journal contains: Web-based BUMDES Accounting Training in BUMDES financial recording and reporting, strengthening BUMDES governance and monitoring and evaluation. The method in this activity is through the socialization of the web-based BUMDES accounting system. The results of this partnership program for the community have created the ability of partners who are able to carry out effective and easy-to-understand financial recording and reporting through learning the web-based BUMDES accounting system. 


\section{RESEARCH RESULTS AND DISCUSSION}

\section{System Design}

To solve the current problem, it is necessary to design an information system for monitoring operational expenditures of the Regional Public Service Agency, so that monitoring of operational expenses becomes more efficient.

\section{Use Case Diagram}

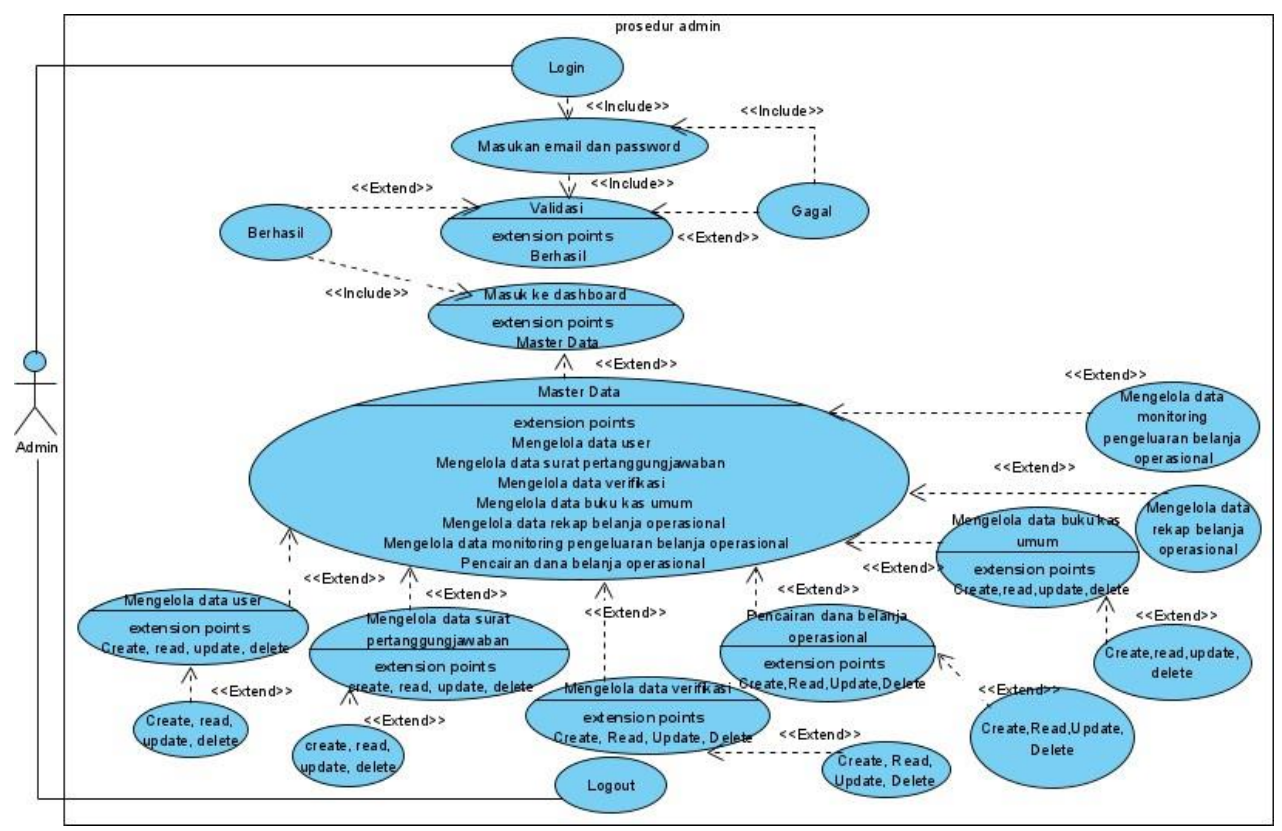

Figure 5. Usecase Diagram of Proposed Admin Procedures

Based on the use case diagram above, it can be explained:

1) One system boundary that describes all admin activities in the system.

2) There is one actor, namely, admin.

3) There is a use case which is described as an interaction between actors and the system, including:

a) Login

$\begin{array}{ll}\text { Usecase } & : \text { Login } \\ \text { Actor } & : \text { Admin } \\ \text { Scenario } & :\end{array}$

1. The actor opens the system

2. The system displays the login page.

3. The actor logs in by entering his email and password

4. The system displays the dashboard

b) Displays the dashboard

Usecase : Enter the dashboard

Actor : Admin 
Scenario :

1. The actor opens the system

2. The actor logs in

3. The system displays the dashboard page.

c) Input user data

Usecase : Manages user data

Actor : Admin

Scenario :

1. The actor enters the system

2. Actor click the user menu.

3. Actors can manage user data to be added, edited, and deleted.

d) Inputting accountability letter data

Usecase : Manage accountability letter data

Actor : Admin

Scenario :

1. The actor enters the system.

2. The actor click the letter of responsibility menu

3. Actors can manage the accountability letter data that will be added, edited, and deleted.

e) Input verification data

Usecase : Manage verification data Actor: Admin

Scenario :

1. The actor enters the system

2. Actor click verification menu

3. Actors can manage verification data that will be added, edited, and deleted.

f) Inputting data on Usecase operational expenditure funds: managing data on disbursement of funds operational expenditure

Actor : Admin

Scenario :

1. The actor enters the system

2. Actors click the menu of disbursement of operational expenditure funds

3. Actors can manage data on disbursement of operational expenditure funds which will be added, edited, and deleted.

g) Inputting the general cash book

Usecase : Manage general cash book data Actor: Admin

Scenario :

1. The actor enters the system

2. Actor click general cash book menu

3. Actors can manage general ledger data that will be added, edited, and deleted.

h) Viewing operational expenditure recap

Usecase $\quad$ : See the operational expenditure recap data Actor: Admin

Scenario

1. The actor enters the system

2. Actors click the operational expenditure recap menu

3. Actors can see the operational expenditure recap data. 
i) View operational expenditure monitoring data.

Usecase : View operational expenditure monitoring data

Actor : Admin

Scenario :

1. The actor enters the system

2. Actors click the operational expenditure monitoring menu

3. Actors can view operational expenditure monitoring data

j) Logout

Usecase : Logout

Actor : Admin

Scenario

1. The actor logged out.

2. The system displays the login page.

3. Actor logs out to exit the system.

\section{Class Diagram}

Class diagrams are very helpful in class visualization of a system. This is because class is a description of a group of objects with the same attributes (properties) and relations. The following is a class diagram of the Monitoring Information System:

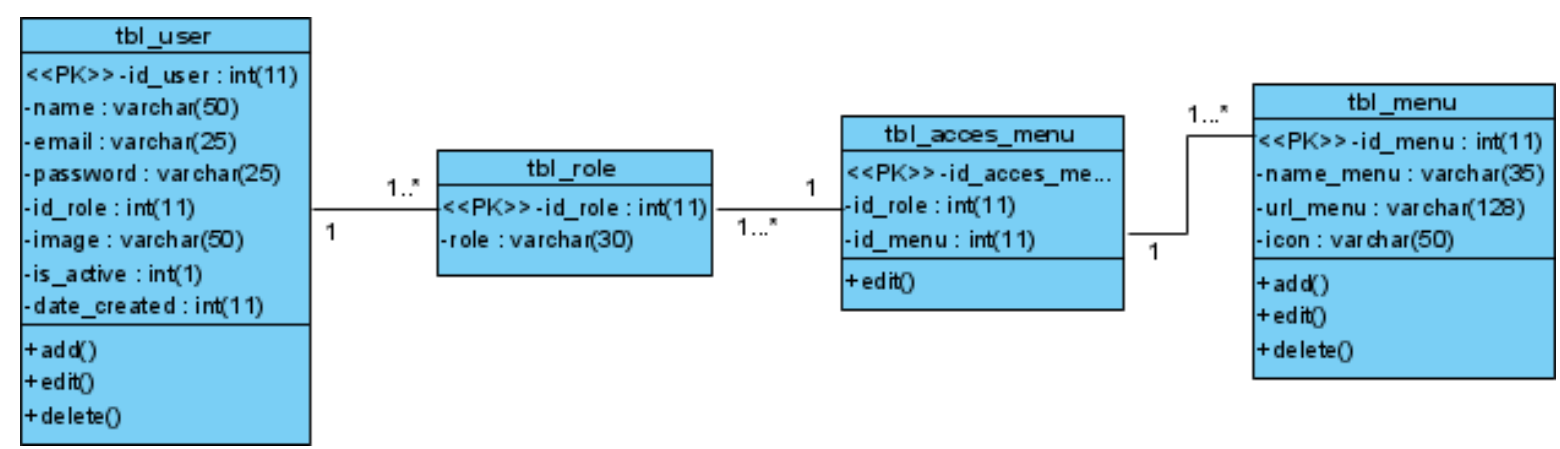




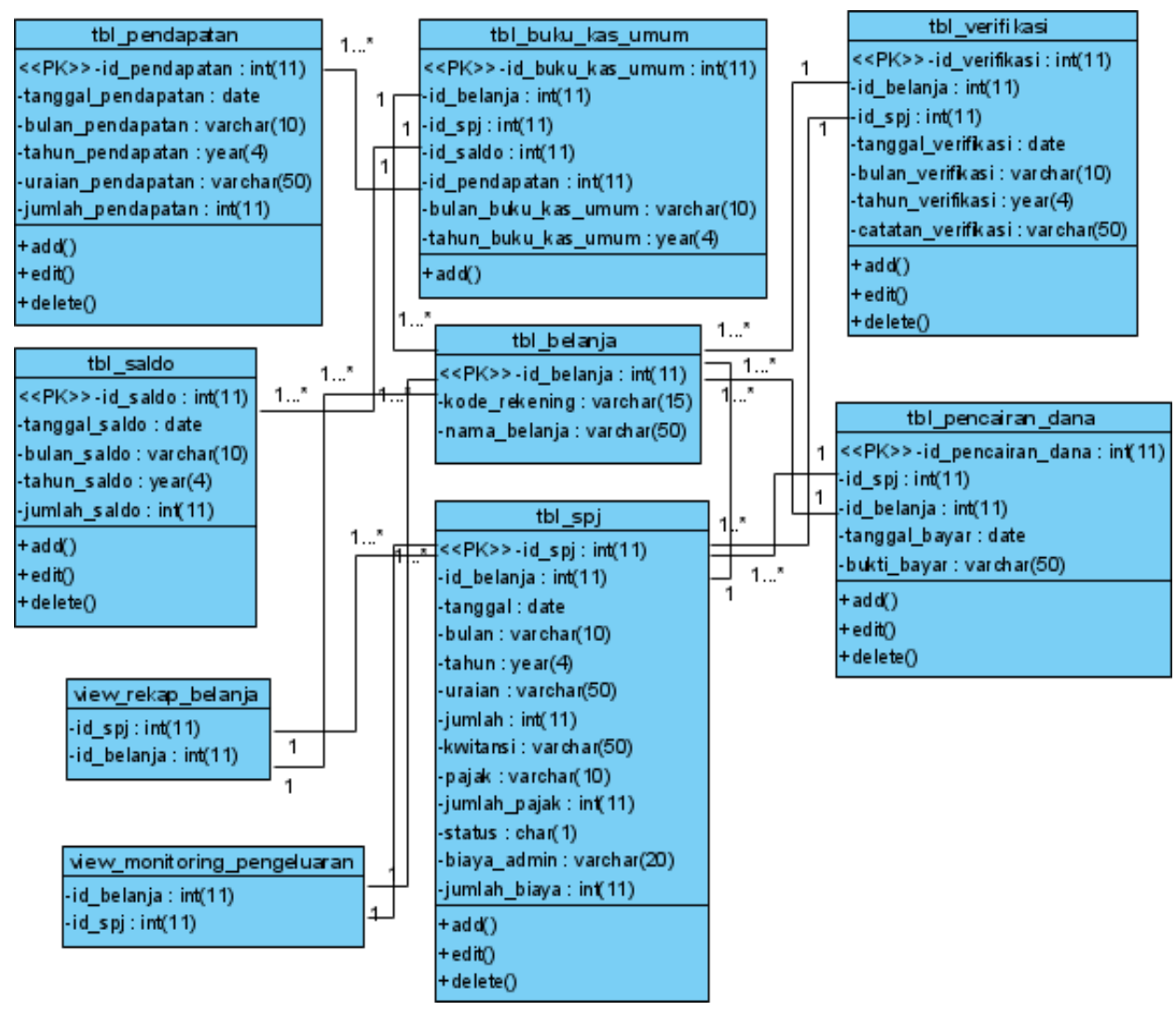

Figure 6. Proposed Class Diagram

\section{Design View}

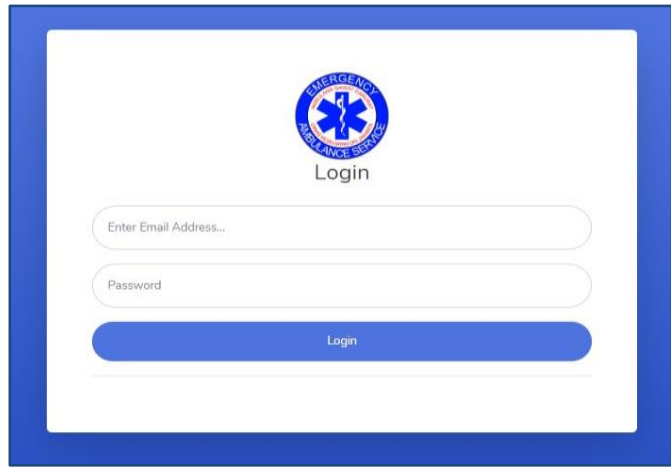

(1)

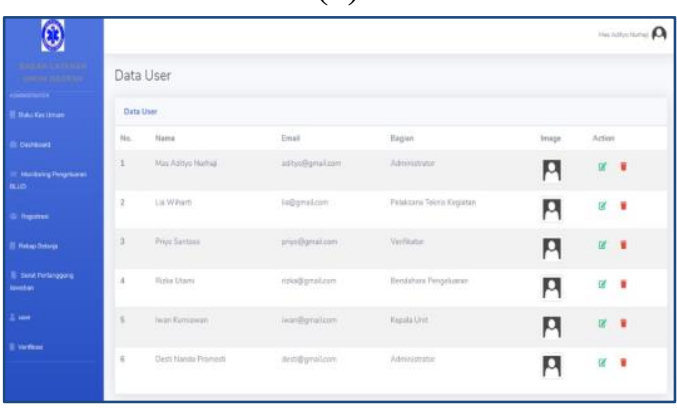

(3)

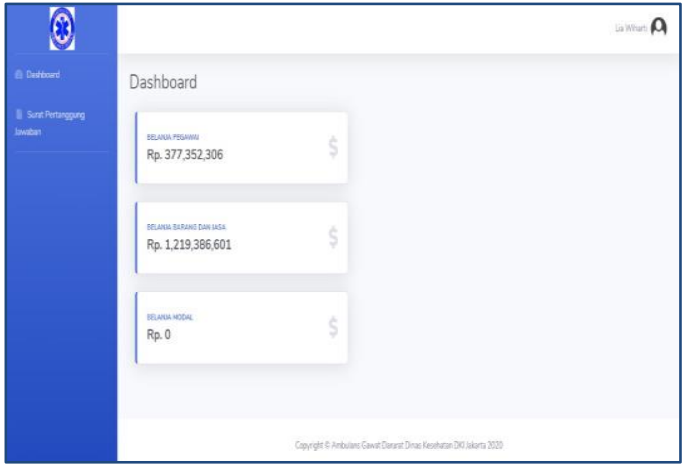

(2)

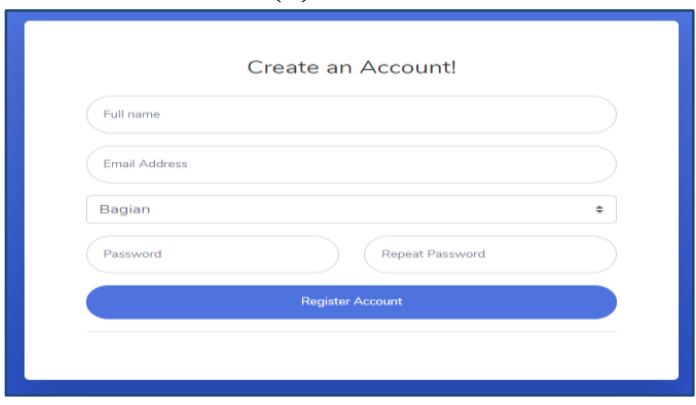

(4) 


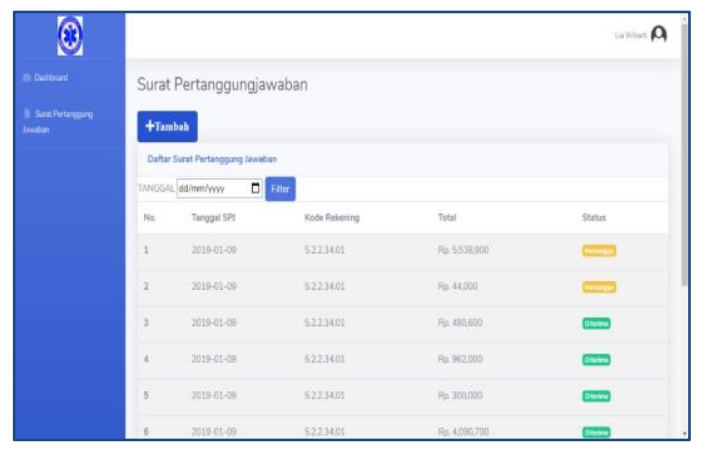

(5)

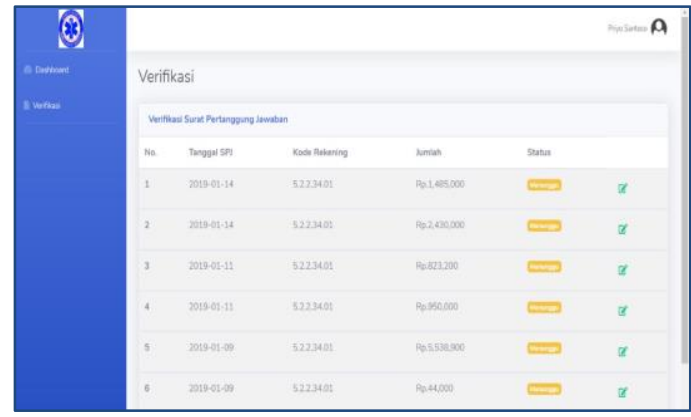

(7)

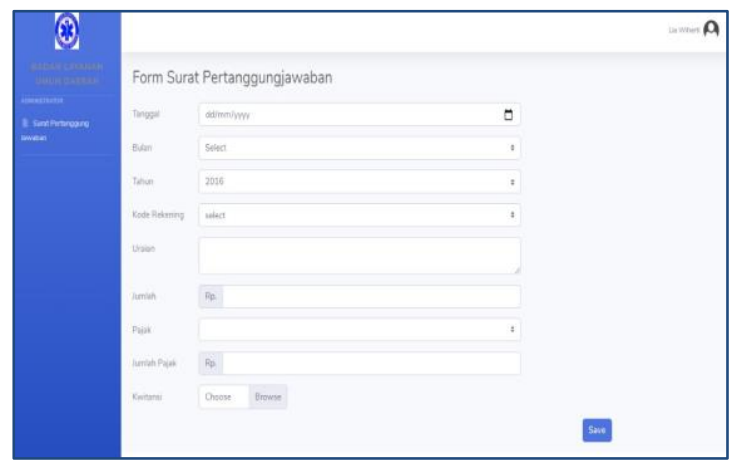

(6)

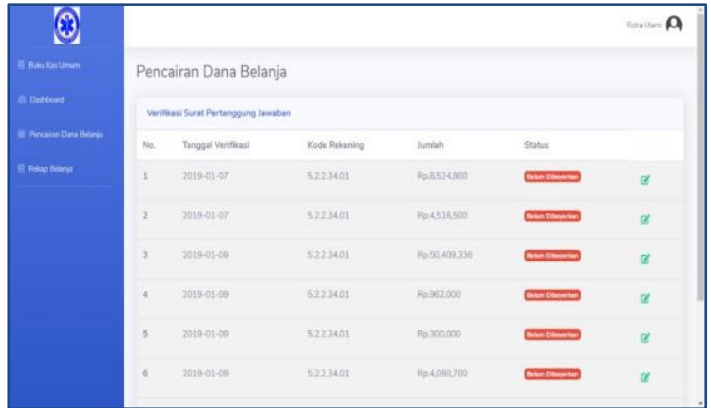

(8)

Figure 6. (1) Login Display. (2) Dashboard display. (3) User Data Display. (4) Add User Data Display. (5) Display of Accountability Letter. (6) Display Add Accountability Letter Data. (7) Display Verification Data. (8) Display of operational expenditure fund disbursement data page.

\section{CONCLUSION}

Based on the results of research and observations from the formulation of the problem regarding the Operational Expenditure Monitoring Information System of the Regional Public Service Agency at the Emergency Ambulance Service Unit of the DKI Jakarta Health Office, the following conclusions can be drawn:

1. The process of monitoring operational expenditures of the Regional Public Service Agency currently running, namely the Technical Activity Implementer of making a letter of accountability, the Verifier will check the completeness of the accountability letter, if the complete data of the verifier makes a verification letter, the Spending Treasurer disbursement of operational expenditure funds to the Activity Technical Implementer via transfer, The Expenditure Treasurer makes a general cash book using Microsoft Excel, at the beginning of the month the spending treasurer performs a recap of operational expenditures, namely classifying the types of operational expenditures, the Expenditure Treasurer provides the results of the recap of operational expenditures to the local government through the SIMPAD website (Regional Original Revenue Management Information System), Financial Services Agency The Regional General Affairs monitors the operational expenditures of the Regional Public Service Bodies, the Regional Public Service Bodies' finances provide the results of monitoring the operational expenditures of the Regional Public Service Bodies to the Head of the Unit. 
2. In the process of monitoring the operational expenditures of the Regional Public Service Agency at the DKI Jakarta Health Service's Emergency Ambulance Service Unit, the problems faced include: The process of monitoring the operational expenses of the Regional Public Service Agency at the DKI Jakarta Health Service Emergency Ambulance Service Unit still takes a long time. Technical Implementation The activity of submitting an accountability letter still has a long stage, the Verifier is not in place so that the process of checking the accountability letter stops, the input of reports is carried out one by one by the Expenditure Treasurer and still uses Microsoft Excel, frequent errors in classifying the types of operational expenditures, adding to financial work regional public service agencies, namely monitoring operational expenditures.

3. To design a monitoring information system for the operational expenditures of the Regional Public Service Agency, using Visual Paradigm to make the UML (Unified Modeling Language) running system and proposals, PHP programming language, MySQL to create databases, CodeIgniter Framework to design systems, Balsmiq to create prototype, and Visual Studio Code as a text editor.

4. The proposed operational expenditure monitoring information system has several advantages, including: submission of an accountability letter can be computerized, the technical activity executor no longer has to include a letter accountability directly to the Verifier, making verification letters can be done computerized, the Expenditure Treasurer no longer enters the general cash books one by one. The system will be automated after the expenditure treasurer disbursed operational expenditure funds and the Expenditure Treasurer only adds balance and income input from the Receiving Treasurer. The Expenditure Treasurer no longer classifies the types of operational expenditures in the operational expenditure recap. As well as the Finance Regional Public Service Agency no longer monitors operational expenditures. So that monitoring of operational expenses becomes more efficient.

\section{SUGGESTED}

To improve the information system for monitoring operational expenditures, there are suggestions from researchers as follows:

1) It is hoped that the development of an operational expenditure monitoring information system can accelerate the monitoring process of operational expenses.

2) It is hoped that the development of an operational expenditure monitoring information system is expected to improve the system even better.

3) It is hoped that the development of an operational expenditure monitoring information system is expected to minimize the occurrence of errors or errors that can be detrimental to users. 


\section{REFERENCES}

[1] Rukun, Kasman. Herawan Hayadi, B. 2018. "Sistem Informasi Berbasis Expert System". Yogyakarta: Deepublish

[2] Mahmud, Rahmad. J. Sondakh, Jullie. S. Budiarso, Novi. 2016. "Analisis Sistem Dan Prosedur Pengeluaran Kas Dengan Menggunakan Uang Persediaan (Up) Pada Dinas Sosial Kota Manado". Jurnal EMBA Vol.4 No.2 Juni 2016. ISSN 2303-1174.

[3] Budiman, Arief. Triono, Joko. 2016. "Sistem Informasi Parkir Kendaraan Bermotor Berbasis Android”. Jurnal Pilar Teknologi. Madiun: Universitas Merdeka Madiun. Vol.1 No.1 Maret 2016. ISSN: 2502-7042.

[4] Irene Putri, Santy. Soultoni Akbar, Prima. 2019. "Sistem Informasi Kesehatan". Ponorogo: Uwais Inspirasi Indonesia.

[5] Nasrudin, Juhana. 2019. "Metodologi Penelitian Pendidikan (Buku ajar praktis cara membuat penelitian)". Bandung: PT. Panca Terra Firma.

[6] Fitra, Halkadri. Agustin, Henri. 2018. "Potret Pola Penyusunan Remunerasi Pada Badan Layanan Umum Daerah Rumah Sakit Umum Daerah Kabupaten/ Kota Di Sumatera Barat”. Jurnal Economac Volume 2 Issue 1 April 2018. ISSN: 1412-3290.

[7] Panambunan, Greivy. J Tinangon, Jantje. 2016. "Evaluasi Pengendalian Internal Dalam Pelaksanaan Sistem Dan Prosedur Pengeluaran Kas Pada Dinas Koperasi Dan Umkm Sulawesi Utara". Jurnal EMBA 907 Vol.4 No.1 Maret 2016. ISSN 2303-1174.

[8] Rosita Arini S, Prima. Wulan Kusuma, Manggar. 2019. "Pengaruh Belanja Modal Dan Pendapatan Asli Daerah Terhadap Investasi Swasta Di Indonesia Dengan Pertumbuhan Ekonomi Sebagai Variabel Intervening”. Jurnal Riset Akuntansi Mercu Buana Vol.5 No. 1. ISSN: 2460-1233.

[9] Idris Patarai, Muhammad. 2016. "Perencanaan Pembangunan Daerah (Sebuah Pengantar)". Makassar: De La Macca.

[10] Umagapi, Darman. Hasan, Syahril. 2019. "Perancangan Sistem Informasi Laporan Pertanggungjawaban Bendahara Pengeluaran pada Kantor Kecamatan Oba Selatan”. Jurnal ilmiah ILKOMINFO Volume 2 Juli No 2 2019. eISSN : 2621-4970

[11] Sugeng Santoso, Oleh Soleh, Siti Humaeroh. 2020. "Aplikasi Jendela Akademik Sebagai Media Komunikasi Orangtua Dan Sekolah Pada BP2IP Tangerang”. Journal Sensi Volume 6, E-ISSN: 2655-5298. 